\title{
Sanat Yaratıcılık Bağlamında İnsan ve Yaratma Güdüsü
}

\author{
Art Creativity and Creation in the Context of Human Motive
}

\begin{abstract}
Leyla AĞLUÇ*
Özet: İnsanoğlu dünyada belirmeye başladığı andan itibaren yaratıcılık onun yaşamının vazgeçilmez bir parçası olmuştur. Doğanın sınırlayıcı ve belirleyici baskısı altında yaşayan insanoğlu, medeni özellikler göstermeye başladığı anda; yani henüz açlık, hastalık ve soğukla boğuştuğu bu dönemde yaratıcılığını öncelikle doğaya karşı başa çıkma yöntemi olarak kullanmıştır. Bu bağlamda insanın, ait olmaya çabaladığı yeryüzünde, kendine bir yer arayışının sonucu olarak karşımıza çıkan yaratıcılık, onun sadece maddeyi şekillendirdiği bir etkinlikle sınırlı kalmamış; yapabilirliğini hissettiği andan itibaren bu özelliğini sanatsal olana yönlendirmiştir. Ve böylece atalarımızın alet yaparak ortaya çıkardığı yaratıcılık genetik bir miras olarak bizlere kadar ulaşmıştır. Sanatsal bağlamda üretenin sanatçı; üretilenin de sanat eseri olarak değerlendirilme ölçütleri bu çalışmanın dışında tutulmuştur. Tartışmak istediğimiz, sanat eseri üretmenin ilahi bir gücün bahşedilmesinin bir sonucu olmadığı, aksine her insanın doğasında var olan potansiyel olduğudur. Konu bu temel üzerinden ele alınarak, sanat, yaratıcılık, insan ve yaratma dürtüsü irdelenmiştir.
\end{abstract}

Anahtar sözcü̈kler: Sanat, insan, yaratıcılık, mağara sanatı, yaratım

Abstract: Creativity has been an indispensable part of humans' life since the moment they first appeared on earth. When people who lived under the limiting and determining pressure of nature began to show civilized characteristics; in other words during the period when they were only fighting against hunger, diseases and cold, they used their creativity primarily as a method of coping with nature. In this context, creativity which came into being as a result of mankind's struggle with nature to which they were striving to belong wasn't limited to just an activity of forming the matter. As soon as they felt that they could perform it, people directed this ability to the artistic field. And thereby we have genetically inherited creativity which our ancestors materialized by producing tools. In the artistic sense the evaluation criteria that a producer is an artist and a produced material is a work of art are left outside this study. What we want to discuss is the assumption that artistic creativity is not a divinely bestowed gift; on the contrary, it is a potential which exists in human nature. Within the perspective of this argument art, creativity, human and motive for creativity have been analyzed.

Keywords: Art, people, creativity, cave art, creation

\section{Giriş}

İnsan var olduğu günden bu yana kendini inşa etme çabası içerisindedir. Aslında kim olduğu nereden gelip nereye gittiği soruları da bu iç çekişmelerin bir sonucudur. İnsanoğlunun binlerce yıldır yaptığı yolculuk onu katman katman oluştururken; yaptığı bu uzun yolculuk, onu kendine doğru da yönlendirmiştir. Bu nedenle insanın kendini konumlandırmaya çalıştığı yeryüzünde yaşamının esas gailesi, kendi tedavisi olmuştur. Tarih öncesinden bu güne evrimleşerek gelen

\footnotetext{
* MA. Marmara Üniversitesi, Güzel Sanatlar Fakültesi, Fotoğraf Bölümü, İstanbul, leyla_agluc@hotmail.com
} 
insanoğlunun, yol bulmasında yaratıcılık ona yol gösterici olmuştur. Hatta ona sadece yol göstermekle de kalmamış insan yaşamının belirleyicisi de olmuştur. Biliyoruz ki insanoğlu yaşadığı ortamdan en iyi yararlanabilme olană̆ını ancak; bilgi, yöntem ve araç-gereçleri en iyi biçimde kullanarak elde edebilmiştir. Bunu ilk gözlemlediği günden itibaren de yaratıcılık, onun yaşamın her alanında görülebilen bir özelliği olmuştur. Bu nedenle insanoğlunun hayatta kalma çabası bir yanda onun yaratıcılığının ortaya çıkmasını sağlarken; diğer yandan aynı kavram, onu sanata doğru yönlendirmiştir. Bu bağlamda ele almaya çalıştığımız insan; düşünen, hayal eden, düş gören ve bunları renk, biçim ve imgelerle, sembolik elemanlar olarak görselleştirme gücüne sahiptir. Sembolik anlamlar taşıyan sanat yapıtı bilinç veya bilinçaltı öğelerinin önceliklerine göre şekillenir. Bilincin ötesi bilinmeyenin ortaya çıkışı, bunun bir sanat eserine dönüşü binlerce yıldır rastlanan bir durumdur. Bu nedenledir ki insan ve onunla ilintili her kavram belli bir s1nırı, çıkmazı ve karmaşayı da beraberinde getirir. Biz de bu zorunluluktan hareketle, klinik psikoloji ve kişilik psikolojisinde etkilerini gösteren ve hala popülerliğini koruyan Psikanalitik Ekol üzerinden, insan yapısı hakkında temel bilgilerle konuyu değerlendirmeye çalışacağız.

\section{Psikolojik Açıdan İnsan}

İnsan hem içten, hem dıştan gelen uyarıcıların karmaşık etkisi (güdü) ile faaliyete geçer ve birtakım hareketlerde (tepki) bulunur. Davranış olarak tanımlanan bu etkileşim, kişiden kişiye, kültürden kültüre dolayısı ile toplumdan topluma farklılıklar gösterir. Bu nedenle insan davranışlarının hangi nedenlerle ve nasıl ortaya çıktığını anlamaya yönelik çeşitli düşüncelere rastlanır. Bunlar, gerek ruhsal gerekse bedensel etkileşimlere dayandırılır. Bu nedenle insan farklı açılardan, farklı yaklaşımlarla ele alınır. Konusu insan olan psikoloji, sosyoloji, antropoloji gibi bilim dallarının çeşitliliğinin de nedeni budur.

İnsanı, anlama ve tanımlama konusundaki ilk çaba, 1879'da Wilhelm Wundt'un ilk deneysel psikoloji laboratuarını kurmasıyla başlar. Böylece psikoloji diğer bilim dallarından ayrı bir disiplin haline gelmiş ve bu alanda insanı farklı bir temel üzerinden ele alan pek çok değişik düşünce ekolü ortaya çıkmıştır. Bunlar; yapısalcılık, davranışçılık, bilişsel yaklaşım, hümanizm işlevselcilik ve psikanaliz, gibi ekollerdir. Psikanalitik Ekol 1895 'te Sigmund Freud tarafından kurulmuştur. İnsan davranışlarının sadece bilinçli süreçlerle açılanamayacağını öne sürmüş olan bu ekol insanın bilinçaltının da incelemesi gerektiğini savunmuştur. Görüş ayrılıkları söz konusu olsa da Jung, Adler gibi isimler de onu takip etmiştir (Psikoloji ekolleri ve yaklaşımları, 2013).

Freud'un psikoanalitik kuramına göre kişilik, id (altbenlik), ego (benlik) ve süperego (üstbenlik) olmak üzere üç ana yapıdan oluşmaktadır. Freud'a göre, yaşamının ilk günlerinde tamamen $i d$ 'den oluşan ilkel bir yapıya sahip olan insan psikesi daha sonra ayrımlaşarak ego ve süperego'yu oluşturur. Ona göre, bu üçlü yapı birbiriyle etkileşerek bireyin davranışlarını yönlendirir. Ego daha çok bilinçli işlemleme yaparken, id ve süperego daha çok bilinçaltı işlemleme yapar. Bu yapı en kaba anlamıyla arzu, mantık ve vicdan olarak da tanımlanabilir. Ruhsal enerji kaynağı olan id, kişiliğin biyolojik parçasıdır. Yemek-içmek, dışkılamak, cinsellikten haz almak gibi tüm dürtülerin kaynağıdır. Kişiliğin ilkel yönü olarak tanımlanan id haz ilkesine göre çalışır. Hiçbir sosyal kuralı önemsemeyen $i d$ ' in tek istediği, isteğinin anında yerine getirilmesidir. Ego, kişiliğin düzenleyici, denge ve uyum sağlayıcı, kısmen de olsa bilinçli bölümüdür. Gerçekliğin sınırlarını zorlamadan, bireyin içsel dürtülerinden kaynaklanan ihtiyaçlarının uygun bir şekilde nasıl karşılanacağını tayin eder ve böylece bireyin dış dünya ile uyum içerisinde yaşamasını sağlar. Kişiliğin ahlaki yönü olan süperego ise, bireyin davranışlarının 
doğru olup olmadığına karar vererek bireyin toplum tarafından onaylanan değer yargılarına göre davranmasını sağlar. Süperego, çocukluk devresinde, çocuğa ailesi ve toplum tarafından aktarılan ödül ve cezalarla pekiştirilerek geleneksel değerlerin etkileşimi sonucu gelişir.

Freud zihni bilinç öncesi ve bilinçdışı olarak iki alana ayırırken, haz ilkesi ve gerçeklik ilkesi üzerinde durmaktadır. Birincil fiziksel içgüdüler olarak değerlendirdiği " $h a z$ ilkesi” bilinçdışında etkisini göstermektedir. Zihnin tehlikeden kaçınma, gerçekliğe uyma ve uygar davranışlarla ilgili bilinçli faaliyetleriyle çatışmaya girebilmektedir. $I d$, fazla enerji birikimine katlanamaz ve böyle bir durum organizmada gerilim yaratır. Kuralsızlık içinde varlık gösteren id fazla enerji birikimine katlanamaz ve böyle bir durum organizmada gerilim yaratır. Bu gerilim gidermek üzere biriken enerjiyi bir an önce boşaltmaya yönelir. Anlık doyuma dayalı tüm güdülerin hemen ve burada giderilmesini ister. Sistem bunların giderilmesi üzerinden çalışır. Ancak haz ilkesinin tatminine yönelik hizmet için bulunan gerçeklik ilkesi hazzın gerçekleşmesi için doğru zaman ve koşulları sağlamaya koyulur. Gerçeklik ilkesi doyumun ertelenmesi ya da ortadan kaldırılması için çalışırken aynı zamanda onu korumaya, sürdürmeye ve doyurmaya yönelik de çalışır. Haz ilkesi çocuklukta baskın olmakla birlikte büyüme ve olgunlaşmayla paralel, azalarak yaşam boyu varlı̆̆ını sürdürür (Freud ve Psikanaliz, 2013, 17).

Freud'un kurduğu psikanaliz ekolünü temelde kabul etmekle birlikte, sonrasında bu ekolü geliştirerek; insanı farklı ve daha geniş yelpazede ele alan, Carl Gustav Jung ise psikenin doğasinı anlayabilmenin; rüyaların, sanatın, mitolojinin, dinlerin ve felsefenin yakından incelenmesiyle mümkün olacağını savunur. Ona göre; gerçekte insan bütünleşmek için çaba göstermez; buna zaten doğuştan sahiptir ve her insan kendini gerçekleştirmek amacı güder. Jung, kişiliği birbiriyle etkileşim içerisinde bulunan çok sayıda sistemden oluşan bir yapı olarak tanımlarken; kişisel bilinçaltı ve kollektif bilinçaltı olarak tanımladığı iki bilinçaltı seviyesinden söz eder. Kişisel bilinçaltı, bilincin hemen altında yer alır ve bireyseldir. Kişisel bilinçaltı, anılardan, arzulardan, dürtülerden, silik algılardan ve unutulmuş kişisel deneyimlerden oluşur. Kişisel bilinçaltındaki deneyimler, gruplaşarak, kompleksleri oluştururlar. Kompleksler, zihin, güç ve aşağılık hissi gibi düşüncelerle meşgul olmasıyla tanımlanan ortak ana konularla, duygu, anı ve isteklerin kalıplarıdır. Bilinçaltının derinlerinde yer alan kollektif bilinçaltı ise kalıtımsal bir nitelik taşır ve insanoğlunun genel evrimsel deneyimlerinden oluşur. Kollektif bilinçaltı, birey tarafından bilinmeyen, geçmişteki henüz insanlaşmamış atalarının da dahil olduğu tüm nesillerin yaşadığı korku, tehlike, mücadele, cinsellik, doğum, ölüm, sevgi gibi tipik psişik etkileşimlerin oluşturduğu deneyimleri kapsar. Jung kollektif bilinçaltını bugünkü insan davranışlarının hepsini yönlendiren, kişiliğin temelini biçimlendiren en etkin güç olarak tanımlamıştır (Özgür, \& Köçer, 2013).

\section{Yaraticılık}

En genel anlamıla [...] bir şeyi yaratmaya iten farazi yatkınlı (http://www.tdk.gov.tr/, 2013) olarak tanımlayabileceğimiz yaratıcılık, insanla yaşıt bir kavramdır. Kavrama yönelik yapılan araştırmalarda, yaratıcılı̆̆ın; hem doğuştan gelen hem de sonradan geliştirilebilir, öğrenilebilir ve hayata geçirilebilir boyutlarının olduğu ortaya konmuştur (Altekin, 2012). Sözcük kimi zaman bilişsel bir süreç; kimi zaman da bir beceri olarak betimlenmiş olup, insanın yaptı̆̆ her etkinlikte; olağan, sıradan, günlük işler diye tanımladığımız etkinliklerden; sanat, teknik ya da bilim gibi karmaşık alanları da kapsayan geniş bir yelpazede gözlemlenen bir olgu olarak tanımlanmıştır (May, 2008, 64). Kavramın Batı dillerindeki karşılığ1 "kreativitaet, creativity” dir. Latince "creare” kelimesinden gelir. Bu kelime, "doğurmak, yaratmak, meydana getirmek" an- 
lamındadır (San, 2008, 13).

Çoğu zaman aynı anlamda kullanılan yetenek ve yaratıcılık kavramları birbirlerinden ayrı anlamlar içermektedir. Bu kavramların, birbirinden ayrışan sınırlarını çizmenin, kavramın daha iyi anlaşılmasına zemin hazırlayacağını düşündüğümüzden, bu iki sözcügün anlamlarını tanımlayarak konuyu ele almaya çalışacağı. Yetenek, çeşitli ifadelerle tanımlanan bir sözcüktür. Bunlar: "Herhangi bir şeyi ögrenmek, bir işi yapmak ve tamamlamak ya da bir duruma başarıyla uymak konusunda organizmada bulunan ve doğuştan gelen güç. 2. Kişinin kalttımsal olarak ögrenmesini çerçeveleyen sinır. 3. Dışarıdan gelen bir etkiyi alabilme gücü" (http://ww tdkterimgov.tr, 2013). Bu tanımlamalara göre yetenek doğuştan gelen ve uyumla ilgili bir şeydir. Yani kişi kullansa da kullanmasa da ona 'verilen' veya 'sahip olduğu bir şeyken; yaratıcılık, ancak edimde görülebilen 'kendiliğinden' var olmayan bir kavram olarak tanımlamaktadır (May, 2008, 67). Bir şeyi yapış süreci içerisinde ortaya çıkan bir kavram olarak yaratıcılık; "yapma" ve "oluş" süreci olarak da tanımlanmaktadır (San, 2008, 13).

Yazılı ve sözlü kaynaklar tarandığında sanattan tasarıma bilimden günlük sıradan işler diye tanımladığımız tüm alanları kapsayan yaratıcılıktan söz edilmektedir. Bu nedenle farklı alanları kapsayan kavrama yönelik birbirinden farklı tanımlara rastlanır. Yaratıcılığı bir çeşit problem çözme olarak gören Torrence'a göre, "[...]boşluklarl, rahatsız edici ya da eksik öğeleri sezip bunlar hakkında düşünüler geliştirmek, varsayımlar kurmak, bunları sunmak, sonuçları karşılaştırıp, değisstirmek ve yeniden sinamak”, Bartlett'a göre, bilinen yoldan ayrılma, yeniye ve deneye açık olma; kısaca kalıplardan kurtulmaktır. Getzels ise yaratıcılığı sezgi ve akılcı imgelemin ve çözümleme yetisinin, hayal kurma ve denetleme ile raksak ve yakınsak birliğine dayandırır (San, 2008, 14). Gartenhaus'un ifadesine göre ise yaratıcılık, "[...]alışkanlık ve kanaat işlevlerinin ötesinde, kişisel keşif, değişim ve yüksek düzeyde anlayışa götüren fikirleri ve olasılıkları oluşturma becerisidir" (Gartenhaus, 2000, 15). Kavramı daha çok sanat alanındaki biçimi ile ele alan Read için yaratıcılık, önceden biçimi ve hiçbir yüzü olmayan bir şeye varlık kazandırmaktır. Ona göre yaratma yoktan var etmek olabileceği gibi, daha çok, var olan malzemenin yeni biçimde kullanımı ve yeni baştan uyarlanmasıdır (San, 2008, 14).

E. Paul Torrance ve J. P. Guilford yaptıkları araştırmalarda yaratıcı kişilerin, düşüncelerini ve fikirlerini oluştururken en azından dört ana yol izlediklerini gözlemlemişlerdir. Elbette bu süreç yaratıcı olmanın tek yolu olarak tanımlanamaz; ancak bunlar yaratıcı düşünme örüntülerini anlamaya yönelik uygun kategorileri temsil etmektedir. Bu özelliklerden herbiri ayrı olarak gerçekleşebileceği gibi tek bir kombinasyon içinde de var olabilirler (Gartenhaus, 2000, 18-19).

"Akıcılık. Akıcı düşünme, bir olanaklar, fikirler ya da sonuçlar niceliği üretmek için kolaylıktır. Akıcı düşünürler oransız miktarda fikirler üretirler. Akıcı düşünürlerin, yorucu gibi görünen bir tartışmadan çok sonra bile 'ekleyecek bir şeyleri daha' vardır çoğu zaman. Esneklik. Esnek düşünme baklş açılarında bir çeşitlilik gelişstirme yeteneğidir. Esnek düşünürler, tek bir soruna pek çok yaklaşma yolu amaçladıkları için bir tür zihin jimnastiği gerçekleştirirler. Esnek düşünürler otoriteye meydan okuyabilirler, çünkü bir şey yapmanın "tek yol"unun seçeneklerini görürler. Özgünlük. Özgün düşünme, alışllmadık, benzersiz ya da yüksek derecede kişiselleşmis yanıtlar ya da fikirler üretme yeteneğidir. Özgün düşünürler ve onların yeni yanıtları garip ya da katıksız biçimde kendine özgü görünebilir. Özgün düşünürler, görevleri ya da sorunlarl çözme yollarıyla çoğu zaman ögretmenlerini, ana babalarını ya da arkadaşlartnı sevindirirler ya da şaşırtırlar. Düzenleme. Düzenleyici düşünme fikir- 
leri genişletme, geliştirme ve süsleme yeteneğidir. Düzenleyici düşünürler ayrintılarla ve ayrintılar tarafindan büyülenirler. Yaptıkları şeydeki 'doku'ya ve 'zenginlik'e başka insanlardan daha fazla aldırış ediyor ya da dikkat yöneltiyor görünmektedirler. Düzenleyici düşünürler çoğu zaman karmaşılk ve karışık şeylere yönelirler" (Gartenhaus, 2000, 18-19).

Kavramın tanımlarına ve sürecine yönelik var olan görüşlerde ortak bazı kavramlara rastlamak mümkündür. Bunlar; [...] 'yeni', 'yenilik', ‘özgünlük', 'buluş', 'sezgi', 'imgelem', 'uslamlama', 'deneme', 'araştırma', 'sınama', 'bulma', 'kalıplardan kurtulma', 'yeniden kurma' gibi zengin anlamlar içeren sözcüklerdir (San, 2008, 15).

$\mathrm{Bu}$ tanımlar ve açıklamalardan yola çıkarak, yaratıcılık kişinin var olmayan bir şeyi belleğinde oluşturabilme, herkesin gördüğü bildiği bir şeyi herkesten farklı yollarla yapabilme ve yeni fikirler geliştirebilme yetisi olarak tanımlayabiliriz. Ancak; diğer yaratıcılık alanlarından farklı olarak, sanatsal yaratıcılıkta; estetik kavramının devreye girdiğini de belirtmeliyiz.

Sanatsal yaratıcıllı̆ın ortaya çıkışına yönelik çeşitli görüşlere rastlanmaktadır. Fromm sanat alanında iki tür yaratıcılıktan söz eder. Birincisi resim yapma, müzik besteleme, roman şiir yazma gibi yeteneğe bağlı, öğrenebilen ve çeşitli yöntemler ve alıştırmalarla geliştirilebilen ve bu sürecin sonunda ürün ortaya konan etkinliklerdir. İkincisi ise; her türlü yaratıcılığın temelinde bulunan, yaratıcı tutum ve davranış biçimidir. Bu türden yaratıcılıkta ürün ortaya konmayabilir. Birinci tür, bir yetenek olarak tanımlanabilirken; ikincisi ise görme, algılama ve tepki verme yetilerinin işlenmesiyle geliştirilebilen karakter özelliğidir (San, 2008, 15). Yaratıcılık; [...] düşünsel, duygusal, entellektüel ve sosyal birçok bileşenin bir arada olduğu ve karmaşık bir beceri (Altekin, 2012) olarak tanımlanıyorsa elbette yaratıc1lı, sanatsal etkinliğin olmazsa olmazıdır. Ancak; yaratıcılık, tek başına yeterli de değildir. Daha önce de ifade ettiğimiz gibi farklı gereksinimleri de olan bu eylemi besleyen, kişinin yaratıcılığını yönlendiren zihinsel malzemeler; imge, hayal gücü, alg1, bellek, imgelemdir.

\section{Yaratıcılık Potansiyeli ve Çevresel Faktörler}

Bilim insanları tarafından, bireylerdeki yaratıcılık potansiyelini saptamaya yönelik çalışmalar gerçekleştirilmiş ve çeşitli bulgular ortaya koyulmuştur. Bu araştırmalara göre en belirgin yaratıcı kişilik özellikleri; kendilerini gerçekleştirme arzusu ve sınırlarını aşma motivasyonu taşımalarıdır (Altekin, 2012). Guilford 1959 yılında deneklerle yaptı̆̆ 1 araştırmada deneklerden tuğlanın kullanılabileceği yerleri listelemelerini istemiştir. Deneklerden biri "ev, okul, baca, barbekü yapımında" gibi cevaplar verirken; diğer bir denek "kapının kapanmasını, kăğtların uçmasını önler, köpeği kovmak için kullanılır" gibi örnekler vermiştir. Deneklerden ilki tuğlayı verdiği tüm örneklerde inşaat yapı malzemesi olarak ele alırken, ikinci deneğin örnekleri çeşitlilik ve esneklik göstermektedir (Erden, \& Akman, 1997, 221). Öte yandan, yaratıcılığın gelişebilirliğine karşılık bazı insanların diğer insanlara oranla daha yaratıcı olduğu da düşünülür. Fakat bu türden bir yaratıcılık çoğunlukla tek bir alanda görülen bir yaratıcılıktır. Leonardo Da Vinci gibi birçok alanda birden yaratıcı olabilen insan sayısı oldukça azdır (Gardner, 2009). Çeşitli araştırmacıların saptadığı değişik yaratıcı kişilik özellikleri listeleri de vardır. Guilford'a göre; yaratıcı özelliklerin en önemlilerinden biri öğrenmeye hazır, istekli ve ilgili olma halidir. Barron'a göre ise yaratıcı birey karmaşıklığı seven, bağımsız, özgüveni yüksek, baskın bir kişiliğe sahip, sınırlamalara ve baskıya karşı çıkan, iletişime açık ve sosyal bir kişilik yapısına sahiptir (San, 2008, 17-18).

Sanatsal eğilimlerin oluşmasında bazı fiziksel yatkınlıkların, avantaj oluşturduğu düşünülmektedir. Konu ile ilgili olarak Soygür, cinsiyette dahil birçok değişkenin kişinin yaratıcılığını, 
hangi yöntem ve alanda ifade edeceğini belirlemede rol oynayabileceğini ifade etmektedir. Ona göre:

"Ĕ̈itimin spesifik formlarl; bireyleri, müzik ya da bilim gibi belirli doğrultularda ilerlemeleri için şekillendirebilir. Yaratıcılık kabiliyetinden farklı olan entellektüel yetenekler de yaratıcılığı şekillendirebilir. Yani bazı kişilerin konuşma becerileri, bazılarının ise görsel ve uzamsal becerileri gelişkin olabilir ve bu imkanlar, ilkinde yazınla ikincisinde görsel sanatlarla uğraşanların yaratıcllı yetilerini ifade etmelerine zemin oluşturur. Son olarak görme yeteneği, boy ve vücuda ilişkin özellikler de yaratıcıllğı şekillendirebilir. Atletik olarak zarif bir vücut yapısıyla doğmuş ya da hünerli elleri olan bir kişinin, problemli ya da hantal bir vücuda sahip olan birine göre dansa ya da müziğe yönelimi daha fazla olacaktır. Toulouse-Lautrec asla bir Nijinsky olamazdl" (Soygür,1999, 133).

$\mathrm{Bu}$ düşünceye göre; sanatsal yaratıcılıkta kişi hangi konuda yaratıcı olacaksa öncelikli olarak o alana özgü gereksinimleri karşılayacak bedensel yatkınlığının olması gerekmektedir. Örneğin; söz konusu alan müzik ise kulağın duyma, algılama yetisi ve ritim duygusu normal insanlara göre daha yüksek olmalıdır. Konu ile ilgili olarak benzer düşüncelere sahip olan Ahmet İnam, Mozart ve Salieri örneğiyle konuya açıklık getirir. İnam, orta derecede bir yeteneğe sahip olan Salieri'nin bestelerini yaparken büyük çaba harcadığını, yani beste yaparken zorlandığını hatta sıkıntı ve 1zdırapla üretimde bulunduğunu; Mozart'ın ise piyanonun başına oturur oturmaz adeta notaların parmaklarından döküldüğünden söz eder ve yeteneğin tek başına yine de yetersiz kalabileceği vurgusunu yapar. Ona göre hangi sanat alanında çalış1lıyorsa çalışılsın aşkla tutkuyla bağlanma, donanım ve sistemli çalışma yaratıcılığın gelişimi için oldukça önemlidir (İnam, 2012). Elbette yaratıcılığın ortaya çıkmasında ve gelişmesinde bu faktörlerin gerekliği tartışma götürmez bir gerçektir; ancak yönelimleri oluşturmada ve geliştirmede çevresel nedenler göz ardı edilemeyecek kadar etkilidir.

Bilim insanları üst paleolitik dönemdeki ustalıklı gerçekçi mağara resim ve heykellerini, mezolotik dönemdeki mağara (küçük çakıl taşları üzerine yapılmış) resim ve heykelleriyle sanatsal anlamda kıyasladıkları çalışmaların sonuçları ilginçtir. Bu araştırmaya göre iki dönem arasındaki fark oldukça barizdir. Mezolitik döneme ait eserlerde gerçeklik zayıflama gösterirken; stilize ve hatta çocuksu sanata doğru bir yönelim olduğu görülmüştür. Bilim insanları, bu gerilemeyi, dönemin sanatçılarının bu alana yönelik yeteneğinin gelişmesi için yeterli zamanın ayıramamış olmasına bağlar. Yeteneğin gelişebilirliğini göstermesi açısından bu örnek de oldukça önemlidir (Şenel, 1982, 132-133).

Yaratıcılığın gelişiminde "çevre" olarak tanımladığımız geniş kapsamlı yapının (aile, eğitim, öğretmen vb. gibi etkenlerin) önemine vurgu yapan Watson'un sözleriyle konuya daha da açıklık kazandırılabilir.

"Bana bir düzine sağllklı bebek ve onlart istediğim şekilde yetiştirme olanağl veriniz. Onlardan tesadüfen herhangi birini alıp yetenekleri, eğilimleri, urk ve ceddi ne olursa olsun seçeceğim herhangi bir alanda yetiştirip meselâ doktor, hukukçu, artist, tüccar, hatta dilenci, hırsız yapabileceğimi garantilerim (Kuzgun, 1972, 168).

Watson'un yaratıcılığın eğitimle olan ilişkisine işaret ettiği bu düşünceleri, yaratıcılık kavramının gelişmesinde ve kavramı farklı açılardan değerlendirmemizde referans kabul edilebilecek niteliktedir. Birçok konuda olduğu gibi yaratıcılık konusunda da doğru yönlendirme yani çevre- 
sel faktör ve eğitim önemli faktörlerin başında gelir. Birçok araştırmanın ortaya çıkardığ 1 bir sonuç olarak önemi sıkça vurgulanan çevresel faktör, Herrman'ın görüşlerinde de kendine yer bulmaktadır. Herrman'a göre ana-baba, öğretmen, eğitim ve kişinin kendi yaşam deneyimleri bazı beyin araştırmacıların ortaya koyduğunun aksine kalıtımdan daha da etkindir (San, 2008, 120). Herrman'nın ortaya koyduğu düşünceler bizim bu konuya yaklaşımız açısından referans niteliği taşımaktadır. Bize göre de genetik yatkınlık ancak; onu açığa çıkaracak ve gelişimine olanak sağlayacak koşulların bir araya gelmesiyle kişiyi, sıradan insana göre avantajlı hale getirebilir. Aksi takdirde yetenek kaybolup gitmeye mahkumdur. Dünya tarihinde önemli sayılan bir bilim adamı ya da bir sanatçıdan bahsederken onların "büyük" olarak nitelendirilmesinde kendilerinin hiç bir çabalarının olmadığını söyleyemeyiz. Aksine, bu doğuştan getirilen yeteneğin yanında özellikle tutkulu ve disiplinli çalışma sistemlerinden; yani azimliistikrarlı tavırlarından söz edilmektedir. Üstünlüklerini ve sıradan olmayışlarını tanımlayan bu sözcükler o insanların tutkularını nitelemek için de kullanılmıştır. May'in de dediği üzere “yaratıcılık sadece gençlik ve çocukluğumuzun masum kendiliğindenliği değildir; yaratıcıllk yetişkin bir insanın tutkusuyla birleştirilmelidir" (May, 2008, 57). Tartışmasız kabul etmeliyiz ki bakış açısının genişletilmesiyle, yenilik arayışı ve merakın desteklenmesiyle, bireye özgün düşünce ve çözüm önerileri için fırsat tanınırsa, var olan yetenek herkes tarafından geliştirilebilir bir özelliktir.

\section{Sanat ve Yaratıcılık Bağlamında İnsan}

Birçok bilim, düşünce ve sanat insanı, hayvanla insan arasındaki farkı yaratıcılığını kullanabilme yani sanat yapabilme özelliğine bağlar. Kierkegaard'ın "ruhun özü ektinliktir" (Blackham, 2005, 26) düşüncesi, sanatı bir çeşit çalışma olarak tanımlayan Marx'ın şu ifadelerinde karşılık bulur:
"Emeği insan türüne özgü bir biçimde düşünmek zorundaylz. Örümcek bir dokumacınınkine benzeyen bir iş yapar. Arı ise hücresini yaparken gösterdiği ustalıkla birçok mimarı utandıracak güçtedir. Ama daha baş- langıçta en beceriksiz mimarı bile arıdan ayıran şey hücreyi balmumuna dökmeden önce kafasında kurmuş olmasıdır" (Fisher, 2005, 19).

Marx, her iki türün de ortaya koyduğu ürünler benzerlik gösterse de insanın ortaya koyduğu eserlerde, "tasarı" ve "bilinç" yeteneğinin açıkça görüldüğünü ve bu ayrıcalığın insanı, ürünlerini güdüsel olarak ortaya koyan hayvanlardan ayıran en önemli özelliklerinden biri olarak tanımlar. İnsanı hayvanlık durumundan ayıran şey çalışma olarak tanımlanıyorsa elbette bilginin, aklın ve deneyimin çalışmanın temelini oluşturduğu da kabul edilmelidir. Vahşi doğada yaşam mücadelesi için alet veya silah yapımı, kendimiz olan hayvanı insanlaştıran bu iki akıl yürütmelerin çıkış noktası olmuştur. Böylece maddeyi biçimlendiren insan, onu amacına uygun hale getirmeyi bilmiştir ama bu işlem; yani yapabilirlik sadece onun istediği biçimi verdiği taş1 değiştirmekle de kalmamış, insanın kendisini de değiştirmiştir (Bataille, 1997, 24).

İnsanoğlu kendi tarihi içinde, doğanın zor koşullarına karşı verdiği yaşam mücadelesini binlerce yıl sürdürmüştür. Bu bağlamda insanın ortaya çıkışı ve izlediği değişimle ilgili bugüne dek birçok hipotez ileri sürülmüştür. İnsanın sonradan gelişerek insan olduğunu ortaya koyan görüşe göre; ön ayakları serbest kalarak dik durabilen insanoğlunun atası (homo-erektus); beyninin büyümesi, besin değerlerinin zenginleşmesi gibi daha birçok nedenle insanın insan olabilmesi için gerekli olan koşulların oluşmasına olanak sağlamıştır. Bu düşünceye göre; ona ayrıcalıklı yer edinmesini sağlayan yegâne organ ' $\mathrm{el}$ ' dir (Fisher, 2005, 19). 
Adler, insanın varlık gösterdiği andan itibaren izlediği gelişmeyi fiziksel sınırlanmalarımıza bağlar ve 'uygarlı̆̆ın fiziksel sinırlanmalarımızdan doğduğu' görüşünü ileri sürer. Bu düşünceden yola çıkarak; sınır ve engelleri, insan varlığı açısından bir "değer" olarak tanımlayabilir ve hatta, çok sık olmamakla birlikte, sınırların kişinin gelişmesini sağlayan itici bir güç olduğu da söyleyebiliriz. Bu bağlamda bir değer olarak tanımladığımız sınırların, sanatsal yaratıcılığın ortaya çıkışı ve gelişimi için de geçerli olduğu söylenebilir. May'in düşüncelerinde de sınırlar, yaratıcı edimin kaynağını oluşturur. Ona göre yaratıcı edim, insanı sınırlayan şeyle birlikte ve ona karşı ortaya çıkan bir etkinliktir (May, 2008, 126).

Evrimi insanın fiziksel yapısındaki değişimle; yani iki ayağının üzerinde durabilmesiyle başladığını ileri süren görüşe karşılık esas evrimin, insanın aklını kullanması sonucu harekete geçirdiği yaratıcı gücü ile başladığını ileri süren görüşlere de rastlanır. Kabaca tarih öncesi çağlar olarak tanımladığımız dönemler içerisinde bile insanoğlunun yaratıcılığını geliştirme çabası içerisinde olduğu dikkati çekicidir (Gönenç, 2007, 93). Günümüze kadar ulaşan insan elinden çıkma ürünler, sanat ve yaratıcılık hakkındaki yorumlar esas alındığında, görüyoruz ki eski çağlardan bu güne gelinceye değin insanoğlunun düşünce ve davranışlarını anlatmak için imgesel anlatım seçtiği en güçlü anlatım şekli olmuştur.

Her yeni bulunan kalıntılarla insanoğlunun geçmişine yönelik bilinenlerin hızla değiştiği bir dönemde yaşıyoruz. İnsanlığa ait her buluntu, sanatın ve insanın kökenine dair doğruluğu kabul edilmiş tüm düşünceleri alt üst ederken; yapılmış olan yorumlarında yenileriyle yer değiştirmesine neden olmaktadır. Yakın zamanlarda keşfedilmiş buluntular bazı bilim insanlarının "insanlık tarihi"nin yeniden yazılması gerektiğini dile getirecek kadar önemlidirler. Son yirmi yılda bu türden zengin örneklerin yer aldığı sayısız önemli buluntu gün yüzüne çıkarılmıştır. Bu eserler daha çok mağara ve tapınak gibi buluntularla birlikte günümüze kadar ulaşan insan elinden çıkma resim, heykel, kabartma ve müzik aletleri gibi eserlerdir. Şimdiye kadar Avrupa'da Buzul Çağına ait iki yüzden fazla resimli mağara, on binin üzerinde taşınabilir sanat olarak adlandırılan nesneler; hayvan yontuları, taş tabletler, mızrak atacakları ve deri kazıyıcıları gibi özenle süslenmiş olan aletler bozulmadan günümüze kadar ulaşmıştır (Levin, 1999, 180). Söz konusu olan bu aletler, insanın en temel ihtiyaçlarını karşılamak üzere yapılmış olmasına rağmen üzerlerindeki süslemeler belirli bir estetik kaygıyı da yansıtmaktadır. Görüldüğü üzere erken dönemde de insanlar her nerede yaşamışlarsa sanat, kültürel etkinliklerin bir öğesi olmuştur (Levin, 1999, 178-179). Yaratıcılığını öncelikli olarak hayatta kalabilmek için kullanmaya başlayan insanın yeryüzünde belirmesiyle aynı zamanlara denk gelen sanatsal üretim, ilkel dönemlerden günümüze kadar insanoğlunun tutkuyla gerçekleştirdiği etkinliklerden biri olmuştur. İnsanoğlu, karnını doyurmak için avlandığı hayvanın ölümünü gerçekleştirecek olan "ok" u sadece öldürme eylemine yarayan bir aletle sınırlamayıp; üzerine yaptığı motiflerle yeni arayışlara da yöneldiğini göstermiştir. Bu dönemin sanatsal dışavurumu olarak gözlemlediğimiz süsleme sanatı silahlarla da (oklarla) sınırlı kalmamış; boncuk yapımı gibi el becerisi isteyen süslemelere de yansımıştır (Levin, 1999, 178-179).

Deneysel Arkeoloji, geçmişteki olayları yineleyerek ya da benzerini yaratarak geçmişin aydınlanmasını sağlamaya yönelik çalışmalar yürütür. Amerikalı arkeolog olan Randall White bu türden çalışmalar yaparak günümüzden 35 bin yıl öncesinde fildişinden üretilmiş olan boncukların yapılış sürecini incelemiştir. White'ın dönemin teknolojik koşullarıyla gerçekleştirdiği bu çalışmaların ortaya koyduğu sonuç şaşırtıcıdır. Bu çalışmaya göre, insan, ancak günde beş boncuk üretebilmektedir. Harcanan emek ve zamanı göz önünde bulundurarak bir değerlendirme yapan White' a göre, boncuklara bu denli çok emek harcayan birinin gözünde doğal olarak değeri de artacaktır (Levin, 1999, 177). 


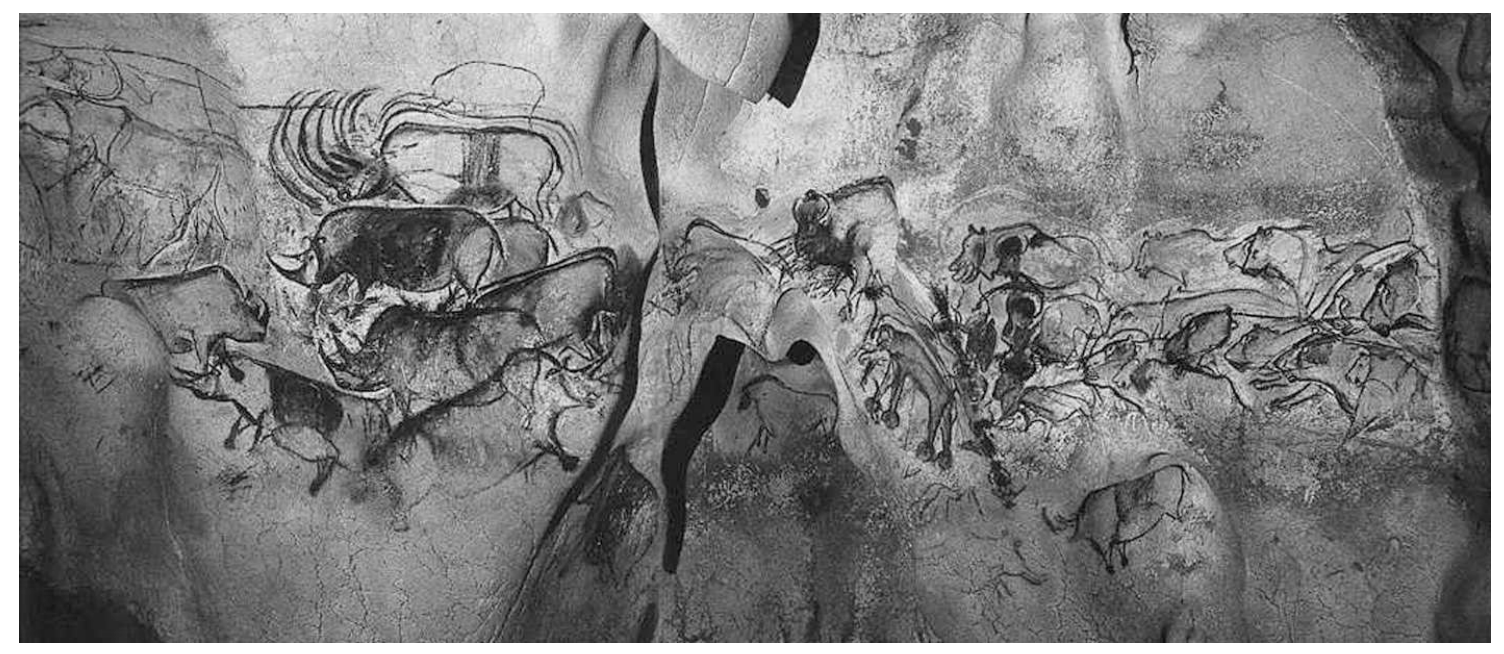

Fig. 1. Chauvet Mağarası.

Bu bağlamda Chauvet Mağarası önemli, zengin bir kaynak olarak karşımıza çıkar. 1994'te gezgin üç arkadaşın rastlantı sonucu keşfettiği Chauvet Mağarası'ndaki resimlerin günümüzden yaklaşık olarak otuz iki bin yıl öncesine ait olduğu söylenmektedir. Renkleri oldukça canlı olan bu resimler, bu güne kadar bulunmuş en gelişmiş örnekler olup; figürlerin anatomileri ve hareketleri mükemmel bir şekilde yansıtılmıştır. Bu resimler; hareket duygusu, perspektif, soyutlama ve anatomik bilginin yanı sıra ileri derecede estetiğe de sahiptirler. Hayvanları temsil için kullandıkları teknik ve özellikle gölgelemede ki ustalık şaşırtıcıdır. Resimlere bu günün bilgisi ile bakıldığında dikkat çeken en önemli şeyin bu resimlerin, ancak akademik alanda eğitim alan kişiler tarafından yapılabileceğini düşündürmesidir (Herzog, 2010). Bugünün insanının kökeniyle yakından bağlantılı olan bu sanata dair hayranlık uyandıran mağara resimlerine değişik dönemlerde de rastlamaktayız.

Dünyanın bilinen en eski insan figürü, 40.000 y1l önce oyulmuştur. Hohle Vels Venüsü olarak isimlendirilen bu figürün 2008 yılındaki keşfine kadar, arkeologlar ilk insan figürünün yaklaşık 25000 y1l öncesinde üretilmiş olduğunu kabul ediyorlardı. Mamut fildişinden oyulmuş bu heykelcik, ne bir kafaya ne de ayaklara sahiptir. Bilim insanları, altı santimetre yüksekliği olan bu figü-

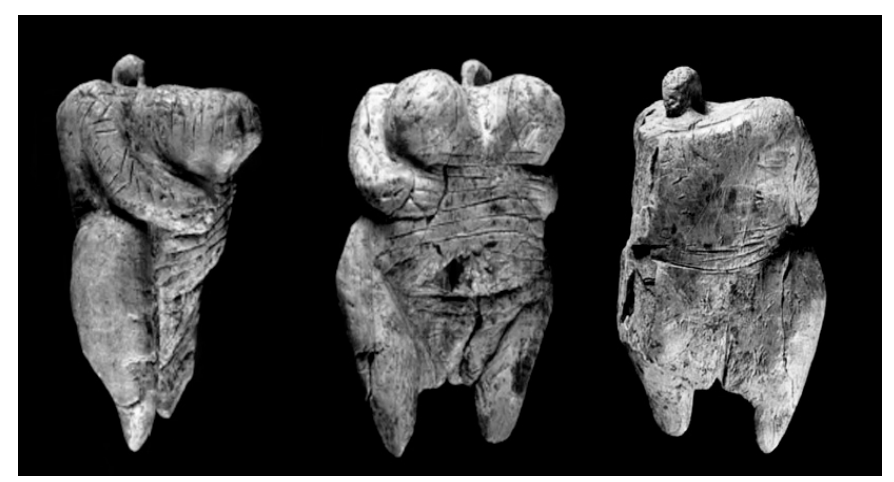

Fig. 2. Hohle Fels Venüsü. rün bir ipin ucunda boyuna asılı bir şekilde kullanıldığını ileri sürmektedirler (Curry, 20013). Bu dönem eserlerin yapılış nedenleri çoğu zaman toteme bağlanmaktadır; ancak burada önemli olan bunların yapılış nedenlerinden daha çok bir ifade biçimi olarak sanatın bir uğraşı haline dönmesidir. Çünkü doğada kendiliğinden var olan bir şeyin değerli sayılması da söz konusu olabilirdi. Ancak; görüyoruz ki kendi elleriyle kendi zihinlerindekilerini yapabiliyor olmaları o dönemin insanı için de önemli ve değerli olmuştur.

Almanya'da bir kazı alanında geçmişi 42-43 bin yıl öncesine uzanan kuş kemiklerinden ve mamut dişlerinden yapılmış flütler bulunmuştur. Gün yüzüne çıkarılan bu flütler, Avrupa'nın bilinen en eski müzik aletleri olma özelliğine sahiptirler. Ancak bu dönemin keşiflerinden biri olarak karşılaştı̆̆ımız flütler, cevaplanması zor soruları da birbiri ardına üretmişlerdir. 


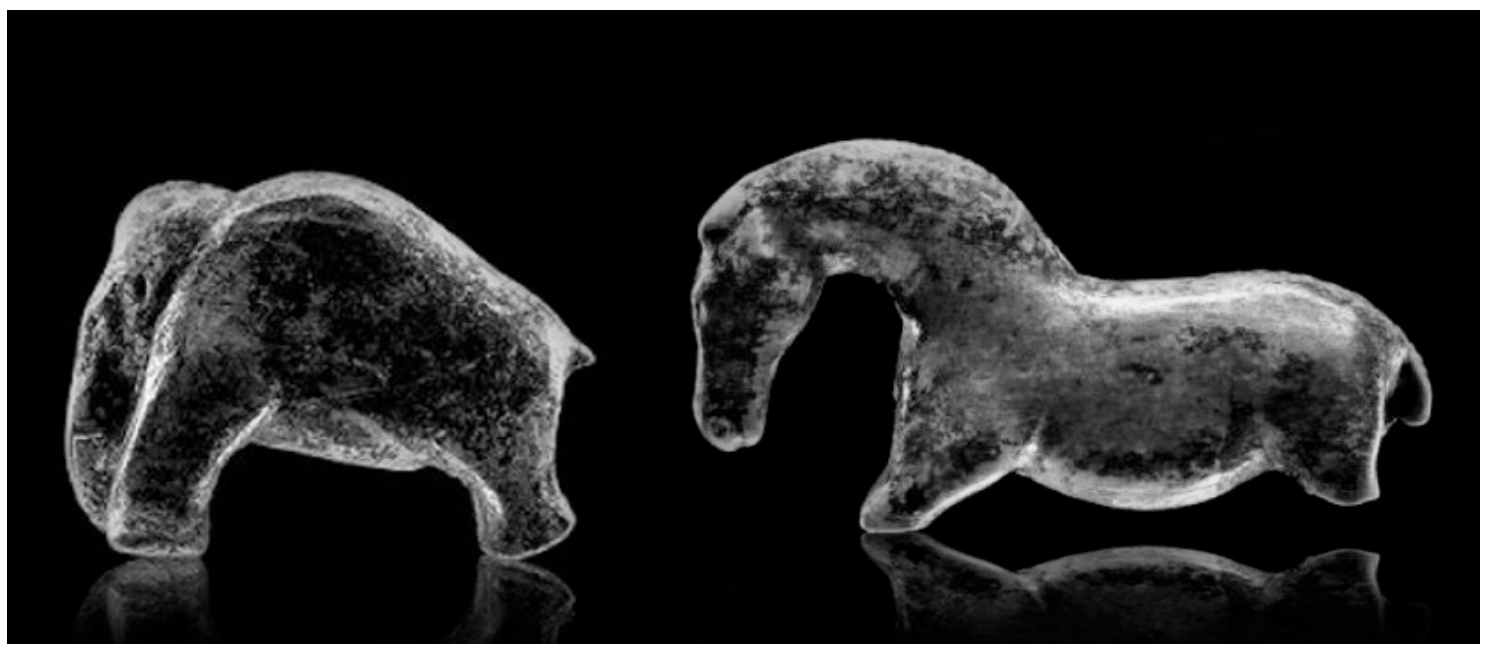

Fig. 3. Paleolitik dönemden kalma mamut fildişinden yapılmış olan mamut ve at heykelcikleri.

$\mathrm{Bu}$ günden geçmişe bakar ve müzik-insan arasındaki ilişkiyi anlamaya yönelik bilinmezlikleri sıralamak istersek; bir kemik parçasını müzik aletine dönüştürmüş olmalarına neyi olarak neden gösterebiliriz? Çıkardıkları sesle dans ya da benzeri figürsel hareketler yapıyorlar mıydı? Ya da flütten nasıl bir ses çıkarıyorlardı? Çıkardıkları ses bizler gibi duygusal şeyler (coşku, keder, hüzün, neşe vb.) yaşamalarına neden oluyor muydu? Soruları daha da çoğaltmak mümkündür; ancak burada bu tür sorulara verilecek yanıtlardan daha çok önemsediğimiz konu şudur; insanoğlunun henüz yaşama (doğaya) uyum sağlama sürecindeyken, doğada örneğini hiç görmediği bir şeyi yapabilmesi bizce oldukça düşündürücüdür. Bu müzik aletlerinin mağara duvarlarına resmettikleri hayvan/insan betimlemeleri veya oyarak/kazıyarak yaptıkları heykel/rölyeflerden farklı bir değerlendirme gerektirdiğini düşünmekteyiz. Bizce insanlar kendileri için önemli olan şeyleri sezmiş/kavramış ve bunu sağlayacak yöntem, araç ve gereçleri de geliştirmişler. Bilimsel platformda yürütülen araştırmalar bilinenleri gün be gün değiştirse de sorular yeni sorulara eklenerek çoğalsa da şunu iyi biliyoruz ki bu eserler insan olmayı başarmış bir türün yeteneğinin ürünleriydi.

İnsanın yeryüzünde var olduğu günden, bugüne gelinceye dek vazgeçilmez bir şekilde süregelen bir etkinlik olarak ele aldığımız sanatsal ediminin yapılış nedenlerine ilişkin, farklı görüşler ileri sürülmektedir. Oldukça çeşitlilik gösteren bu görüşlerde; sanatın psikolojik nedenlere, büyü temelli bir yapıya, doğaya karşı duyulan korkuya ya da oyun içtepisine bağlı olarak yapıldığ yönünde düşüncelere rastlanmaktadır (Altınkaş, 2007). Bazı araştırmacılara göre; alet yapmakla düşünce sahibi olmaya başlayan ilkel insan, beraber yaşam sürmenin bir sonucu olarak iletişim sistemlerini de geliştirmiştir. Böylelikle konuşma ile düşüncelerini aktarmaya başlamıştır. Törensel gömülerinden anlaşılacağı üzere, sistemli düşüncelere sahip olacak noktaya varmış ve sihir yöntemleriyle doğayı düşüncelerle etkileme yolunda da ilk adımını atmıştır. $\mathrm{Bu}$ topluluklarda düşünce aktarma işini o toplumun yaşlıları yerine boş zaman uzmanları sıfatıyla tanımlanan sihirci sanatçılar üstlenmiş görünmektedir. Topluluğun düşüncesini az çok sistemleştirme, ona yeni çıkış noktaları kazandırma yolunda işlev görmüş olduğu düşünülen sihirci sanatçılar toplumsal yapı içerisinde düşüncenin rolünün, yoğunluğunun artmasına da yol açmış olabilirler. Uzman avcı topluluklarında sihirsel düşünüşün olgunluğa ulaştı̆̆ söylenebilir. Bunu törensel gömülerinde, mağara ve kaya resim, gravür ve kabartmalarında, hayvan heykelciklerinde ve "venüsler" de, tılsıml süs eşyalarında bol bol görüyoruz. Çağdaş ilkellerde görülen sihir türlerinin yardımılla, bu "sanat" ürünlerinin çoğunun "av sihiri", bir kısmının 
"doğurganlık sihiri" olduğu anlaşıllyor. Av sihiri geçimle (üretimle) doğurganlık sihiri yaşamın (ortak çalışmaya katılacak kimselerin) yeniden üretilmesiyle ilgilidir. "Analoji sihiri", "birlik duygu sihiri", "bulaşıcı sihir" gibi sihir biçimlerinin de benzetmeci düşünüşün çeşitli biçimlerinin ürünleri oldukları açıkça görülüyor (Şenel, 1982, 112. 115-116).

Tüm bu ileri sürülen nedenler günümüze kadar varlığını her koşulda sürdüren sanatı anlayabilmemiz için elbette çok önemlidir. Fakat insanoğlu o veya bu nedenle üretiyor olabilir, şu veya bu araç gereci de seçmiş olabilir, bizce burada dikkat çeken şey; henüz doğa koşullarıyla mücadele ettiği dönemde dahi yaratıcılığını sanatsal alana yönlendirmiş olması ve bu eyleme tutku ile bağ l1lığıdır. Açıkça görülüyor ki insan dünyada var olduğu andan itibaren insan ve sanat; sanat ve yaratıcılık birbiriyle iç içe geçmiş kavramlardır. Tüm bu düşünceler temelinde insan ve sanat arasındaki bağın, sanat ve yaratıcılık arasında da olduğunu söyleyebilir ve hatta bu kavramların birbirinden ayrı düşünülemeyecek olgular olduğu sonucuna da varabiliriz.

Sanat kavram olarak üretilen, konuşulan, tartışılan, eleştirilen nihayetinde geliştirilen bir şey de olsa temelde insan sanatı önemli bir ihtiyacını karşılamak için yapmaktadır. O da kendini başkalarına anlatma ihtiyacıdır. Sanat yapmanın gerekliliği toplumda yaygın olarak bireyin kendisini ifade etme biçimi olarak tanımlanır. Bilim insanlarının tanımıyla bu; kendini gerçekleştirmedir. Kendini gerçekleştirme kavramı Jung'un ortaya koyduğu bir kavram olmakla birlikte; Adler, Rank, Goldstein, Fromm'un çalışmalarında da kendine yer bulmuştur. Bu, en genel anlamıyla insanın, içinde kendiliğinden var olan insan olma potansiyelini ortaya çıkarması olarak tanımlanabilir. Hümanistik ekole göre insanın beslenme, korunma, nesli sürdürme gibi temel fizyolojik ihtiyaçları vardır ve bu temel ihtiyaçlar giderildikten sonra daha üst seviyede ihtiyaçları ortaya çıkar ve hayatı boyunca bunları doyurmaya çalışır. Maslow'un tümüne birden "gelişme ihtiyaçları" dediği bu üst düzeydeki ihtiyaçlar, saygı görmek, bilgi edinmek, güzellikten zevk almak gibi ihtiyaçlardır. Hümanistik psikologlar kendini gerçekleştirme güdüsünün insan davranışlarını yöneten en önemli güdü olduğunu ileri sürmektedirler (Kuzgun, 169-171, 1972). Sanat yapma edimini bu bağlamda değerlendirdiğimizde Köknel'in "Genelde her sanat yapıtının altında kendini gerçekleştirmeye çalışan bir insanın çabası, her insanın içinde de bir sanat yapıtının tohumlarının bulunduğu söylenebilir" (Köknel, 2012) sözü oldukça önemlidir. Ancak yine de bu potansiyelin her insanda var olduğunu düşünsekte sanatı kullanabilmek [...] için yaşantiyl yakalayıp tutmak, onu belleğe, belleği anlatıma, gereçleri biçime dönüştürmek gerekir (Fisher, 2003, 11).

Kendini gerçekleştirmeye dair sanatsal alanın kullanılmasına en çarpıcı örneklerden biri Nazi toplama kampında gerçekleşmiştir. İkinci Dünya Savası sırasında Nazi kampında esir düşen ve ölümü bekleyen bazı çocuk ve yetişkinlerin yaptıkları eserler 1948 yılında Paris Modern Sanat Müzesinde özel bir salonda sergilenmişti (Yetkin, 1968, 125). Bu sergide dikkat çeken ilk şey resimlerin sigara paketlerinin arkasına ve gizlice ele geçirilen kâğıtlara, heykellerin ise kırık dökük masa ve sandalye bacakları oyularak yapılmış olmasıydı. Sergilenen eserlerdeki konular kampta kaldıkları süreçte yaşanan korku, işkence ve acı temalı sahnelerden oluşmaktaydı. Bu sergide göze çarpan şey; o insanların, umutlarının tükendiği bir zamanda bile onca acı ve işkenceye rağmen yaşadıklarını, hissettiklerini anlatmaktan kendilerini alamamalarıdır. Nazi kampından kurtularak hayatta kalmayı başaranlardan biri, o zor ve korku dolu anlarda yaptıkları bu etkinliği "Her gün yaşayabilmek için bunu yapmak zorundaydlk" şeklinde ifade etmiştir (Yurtsever, 2013). Bu ifadenin benzeri Sait Faik Abasıyanık'1n "yazmasaydım çıldıracaktım” sözlerinde rastlanır. "Kuşkusuz insan sonlu bir varlıktır ve özgürlüğü de sinırlıdır. Bu koşullardan özgürlük değil, koşullara yönelik bir tavır alabilme özgürlüğ̈̈dür” (Frankl, 2009, 144). Yaratıc1 bir yetenekle dünyaya gelmiş olan insan, bunu insan olmanın olağan sınırlılığının dışında; yani fiziksel sınırlanmalar karşısında da kuşkusuz doğasındaki ölümsüz olma güdüsüyle bu yetene- 
ğine bir çıkış yolu bulma gereksinmesi duyacaktır.

Yukarıdaki örneklerden ve düşüncelerden yola çıkarak insanın, ölüm korkusu ile başa çıkmak için sevinçlerini, üzüntülerini, umutlarını, düşüncelerini kısaca kendini ifade etmek için, yaratıcılığını; yani sanatı bir araç olarak kullandığı söylenebilir. Üstelik bunu ihtiyacını hissettiği her durum ve koşulda, herhangi bir araç ve gereçle gerçekleştirmenin yollarını aradığ 1 da göz ardı edilemeyecek bir gerçektir. Bu bağlamda son söz olarak diyebiliriz ki; "Kuşkusuz insan yaşamı, salt fiziksel gereksinimlerin giderildiği ve çalışmayla geçen bir süreç olsaydl, ne kadar da kuru, yavan, tatsız ve içi boşalmış olurdu” (Ezici, 2005, 122-127).

\section{Sonuç}

Bilim insanları tarih öncesine ait sanatsal kalıntıları, daha çok o dönem insanının yaşam örüntülerini anlamak üzere inceleseler de, ortaya çıkan yorumlar birbirinden farklılık gösterse de gördüğümüz şey; sanatın, insan yaşamının vazgeçilmez öğesi olduğudur. İnsanoğlunun hayatını kolaylaştırmak üzere yaptığı aletlerle ortaya çıkardığı yaratıcılık, çok geçmeden sanatsal olana doğru köprü oluşturmuş ve onu sanatsal edime doğru yönlendirmiştir. Kendi tarihi boyunca insanoğlu, bir şeyler yaratmaya başladığı günden bu güne değin hiç durmadan ve her koşulda yaratıcılığını kullanarak ürünler gerçekleştirmektedir. Hepimiz, küçücük bir çocuğun bir melodi duyduğunda müziğin ritmine eşlik etmesine ve eli şekil verilebilir bir maddeye temas ettiğinde onu bir şeylere benzetmeye veya dönüştürmeye çalışmasına tanık olmuşuzdur. Görülüyor ki insan gördüğünü, algıladığını, hissettiğini dışa vurma ihtiyacı duyan, bunu da çeşitli yöntemler ve araçlarla gerçekleştirmeye çalışan bir tavır içerisindedir. Bu bağlamda sanat, sanatçı olsun olmasin tercih edilen bir yöntemdir.

Tarih öncesi dönemde üretilen eserlerin sanat olup olmadığı tartışmalarını bir kenara bırakırsak; bu eserlerin günümüzün modern insanının gereksinimleriyle aynı nedenlere dayanılarak yapılmış olabileceğini düşündürtmektedir. Tarih öncesinde bu aktiviteyi yapan insan da, günümüz insanı da kendi algısı üzerinden kavramaya çalıştığı dünyayı, yine kendi algısıyla ortaya koymaktadır. Konular değişim gösteriyor olsa da üretilenin merkezde insan ve onun yaşam mücadelesi vardır. Doğal olarak insan yaşamı, neyi içeriyorsa; bu yarattığına yansıyacak ve her zaman insanoğlu sanatta varlığını arayacak; onda bulacak ve bizlere de bunu gösterecektir. Sanatın, insanın var olduğu andan bu yana yaşamının vazgeçilmez bir unsuru olarak gözlemlediğimiz bir etkinlik olduğu göz önünde bulundurulduğunda; insanın bu etkinliği gerçekleştirmeye güçlü bir gereksinim duyduğu sonucuna varılır. Günümüze kadar üretilen eserlerin çokluğu, çocuk üzerinden örneklendirdiğimiz güdüsel eylem ve daha önce yer verdiğimiz Nazi Kampında esirlerin ölümle burun burunayken ürettikleri eserler bir araya geldiğinde bu çıkarım daha da güçlenmektedir.

İnsanın var olduğu andan itibaren hayatının vazgeçilemez bir öğesi olarak gözlemlediğimiz bu etkinlik, süreç içerisinde insan yapısının doğal bir parçası haline dönüşmüştür. Her an çevrimizde karşılaşabileceğimiz sanatsal etkinlik, sanatçı olsun olmasın her insanın doğduğu andan itibaren bu potansiyeline sahip olduğunu gösterir. Biz bunları entelektüel bağlamda "sanat" olarak değerlendiremesek de kendini gerçekleştirme güdüsünün bir sonucu olarak değerlendirmek mümkün görünmektedir. İnsan bağlamında konuyu ele alan Jung bunu kolektif bilinç olarak tanımlar. Ona göre "yaratıcı fikirler kaynă̆ $l$ " insanların içinde, derinlerde yer alan ve asla tüketilemeyecek olan sonsuz üretkenlik kaynağıdır. (Keçe, 2013). Jung'un yaratıcı fikirler kaynağının izlerini Adler'in düşüncelerinde de görmek mümkündür. Ona göre, "insanın kendisinde gözlemleyeceği ilk şey hiç durmadan bir hedefe ulaşma çabasında olmasıdır" (Adler, 
2004, 26-27). Jung'un Freud'dan fazla olduğu vurgusu yapan Saydam, Jung'un fikirlerini kaleme aldığı makalesinde şu ifadeye yer vermiştir; "İnsan yaşamının esas gailesi, kendi tedavisidir, yani kendi eksikliklerini tamamlamak, çatışmalarını çözümlemek ve zedelenmişliklerinin ıstırabını azaltmaktır. Bunu başarmak, dünyayı, yeniden ve merkezinde kendisi olmak kaydıyla, yani, kendi dünyası olarak -tamam etmektir: -Yaratıcılık dediğimiz, hiç bitmeyecek, yani hiçbir zaman ufkuna ulaşılamayacak eylem de budur: -Dünyayl-tamam-etme-eylemi..." (Saydam, 2010, 2).

Tüm bu düşünce ve örnekleri bir araya getirdiğimizde şu sonuca varmak mümkündür. İnsan kendini var edecek bitmez tükenmez bir kaynağa sahiptir ve bu kaynak doğal olarak insanı bir şeyler yapıp etmeye yönlendirecektir. Bu yapıp etmelerin de tek bir amaç için olduğu düşüncesi hakimdir. $\mathrm{O}$ da hümanistik psikologların kendini gerçekleştirme olarak tanımladıkları insanın var olan insan olma potansiyelini kullanmasıdır. Sanat da bu amaç için en uygun araçtır.

Görülüyor ki; her çağda ve her koşulda insanlar sanata her daim gereksinim duymuş ve sanatla iç içe olmuştur. Bu nedenle insan var olduğu andan itibaren, sanat insan ve yaratıcılık arasında bir biriyle sıkı sıkıya bir bağ oluşmuştur. İnsanın varlığı devam ettiği sürece bu iç içelik ve gereksinimde hep var olacaktır. Çünkü sanatsal yaratımın merkezinde insan ve onun yaşamla ilişkisi yer alır; bu da göstermektedir ki "İnsanlık ölmedikçe sanat da ölmeyecektir" (Fisher, $2005,220)$. 


\section{KAYNAKÇA}

Adler, A. (2004). İnsanın Doğası. Çev.: Ayşen Tekşen Kapkın. İstanbul: Payel Yayınevi

Bataille, G. (1997). Eros'un Gözyaşları. İstanbul: Göçebe Yayınları.

Blackham, H. J. ( 2005). Altı Varoluşçu Düşünür. Ankara: Dost Yayınevi.

Erden, M., \& Akman, Y. (1997). Eğitim Psikolojisi. Ankara: Arkadaş Yayınları.

Ezici, A. K. (2005). "Sanatçının Kişiliği ve Yaratma Psikolojisi”. Anadolu Psikiyatri Dergisi, 6, 122-127

Fisher, E. (2005). Sanatın Gerekliliği. Çev.: Cevat Çapan. İstanbul: Payel Yayınları.

Frankl, V. E. (2009). İnsanın Anlam Arayış̧ı. Çev.: Selçuk Budak. İstanbul: Okuyan Us Yayınevi.

Gartenhaus, A. R. (2000). Yaratıcı Düşünme ve Müzeler. Çev.: Onur Bekir, \& Ruhiser Mergenci. Ankara: Ankara Üniversitesi Basımevi.

Gönenç, E. Ö. (2005). “İletişimin Tarihsel Süreci”. İstanbul Üniversitesi İletişim Fakültesi Dergisi, 28, 93105.

Levin, R. (1999). Modern Insanın Kökeni. Ankara: Tübitak Yayınları.

May, R. (2008). Yaratma Cesareti. Çev.: Alper Oysal. İstanbul: Metis Yayınları.

San, İ. (2008). Sanat ve Eğitim. Ankara: Ütopya Yayınları.

Saydam M. B. (2010) "Postmodern Gnostik Olarak C. G. Jung ve Analitik Psikoloji Okulu". Nef(e)s Nörofelsefe Dergisi, 3, 8-15.

Şenel, A. (1982). Illkel Topluluktan Uygar Topluma Geçiş Aşamasında Ekonomik Toplumsal Düşünsel Yapıların Etkileşimi. Ankara: Ankara Üniversitesi Siyasal Bilgiler Fakültesi Yayınları.

Soygür, H. (1999). "Sanat ve Delilik". Klinik Psikiyatri Dergisi, 2 (2), 124-133.

Kuzgun, Y. (1972). "Kendini Gerçekleştirme". Ankara Üniversitesi Dil ve Tarih-Coğrafya Fakültesi Felsefe Bölümü Dergisi, 10, 163-178.

Yetkin S. K. (1968). "Sanat Eğitiminin Eğitimimizdeki Yeri”. Ankara Üniversitesi Eğitim Bilimleri Fakültesi Dergisi, 1 (1), 125.

\section{İnternet Erişimleri}

Altekin, S. (2012). "Yaratıcllk Potansiyelini Bir Beceriye Dönüş̧türmek Mümkün". http://www.Serapaltekin com/Yaraticilik.php

Altınkaş, C. B. (2007). "Sanat ve Oyun". Bilim Eğitim ve Düşünce Dergisi. 7 (2). Kaynak: http://www.universite- toplum.org/text.php3?id=370

Atatürk Kültür, Dil ve Tarih Yüksek Kurumu, (2013), Kaynak: ttp://www.tdk.org.tr

Atatürk Kültür, Dil ve Tarih Yüksek Kurumu, (2013), Kaynak: http://www.tdkterim.gov.tr

Curry, A., (2012) "Mağara Sanat Tartısmaları". Kaynak: http://www.smithsonianmag.com/historyarchaeology/The-Cave-Art-Debate.html

Freud ve Psikanaliz, Araştırma Serisi No. 4217 Kaynak: http://www.psikiyatrcom/other/freudve psikanaliz.pdf

İnam, A., Güleç, C., Kılıçbay, M. A., (2012) “Ne Diyoruz Ne Anlıyoruz - Yetenek ve Yaratıc1lı" [Video File], Kaynak: http://www.youtube.com/watch?v=Y4Y5UDta3Bg

Köknel, Ö. (2012). "Çalışma Yaratııllı ve Sanat” Kaynak: http://www.aymavisiorg/psikoloji/Sanat\%20\%20Ozcan\%20Koknel.html

Psikoloji Ekolleri-Yaklaşımları, (2013), Kaynak: Yurtsever, A. (2013), "Sanat ve Çocuk". Kaynak: http://www.dbe.com.tr/tr-TR/Content/ Default.aspx?SectionID=905+

http://www.felsefedersligi.com/FileUpload/op30412/File/psi._ekoller-tablo.pdf.

Özgür N., Köçer Ş, “Carl Custav Jung” (2013), Kaynak:http://dergi.aktiffelsefeor.index.php?option comcontent\&viewarticle\&id74:nurdanoezguer-uekriye koecer\&catid=19:68\&Itemid=27

Film

Herzog, W. (Director). (2010). Cave of Forgotten Dreams [Documentary Film]. Creative Differences. 